\title{
INDICES OF LIPID PANEL IN PATIENTS WITH ESSENTIAL HYPERTENSION, COMPLICATED WITH HEMORRHAGIC STROKE, AFTER AN EARLY RECOVERY PERIOD Oleksandr V. Tkachyshyn
}

\section{ПОКАЗНИКИ ЛППДОГРАМИ У ХВОРИХ НА ГІПЕРТОНЧНУ ХВОРОБУ, УСКЛАДНЕНУ ГЕМОРАГІЧНИМ ІНСУЛЬТО, ПІСЛЯ РАННЬОГО ВІДНОВНОГО ПЕРІОДУ}

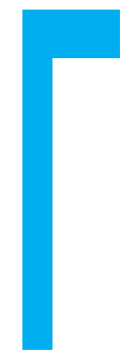

ТКАЧИШИН О.В.

Національний медичний університет

ім. О.О. Богомольця, м. Київ, Україна

\section{Ключові слова: геморагічний інсульт, гіпертонічна хвороба, ліпідограма, атеросклероз, статини.}

еморагічний інсульт (ГІ) є тяжким захворюванням, яке часто призводить до смерті та тяжкої інвалідизації. Головним чинником ризику розвитку ГІ Є артеріальна гіпертензія (АГ) [5]. Загальновідомим фактом $€$ коморбідність між АГ та атеросклеротичним ураженням судин [2]. Доведено, що при атеросклерозі зниження підвищеного рівня загального холестерину (3X) та ліпопротеїдів низької щільності (ЛПНЩ) сприяє зниженню ризику розвитку серцевосудинних подій та смерті 3 будь-яких причин $[8,15]$. Втім, у багатьох дослідженнях існують суперечливі дані щодо доцільності та безпеки корекції показників ліпідограми у пацієнтів, які перенесли ГІ, що обґрунтовується підвищеним ризиком повторних кровотеч
[23]. Проте існують досить обмежені відомості щодо підгрупи пацієнтів з ГІ, асоційованим передусім з АГ, для яких проблема атеросклерозу $\epsilon$ актуальною, зважаючи на вищезазначену коморбідність. Крім того, майже всі проведені дослідження стосуються перших 3-х періодів ГІ [1], але відомо, що починаючи з 4-го пізнього реабілітаційного періоду (>6 міс. після ГІ) + ризик повторного ГІ знижується [5], а зміни серцево-судинної системи мало досліджені у такої категорії хворих. При цьому перенесений ГІ призводять до значного ризику смертельного наслідку з 1-річною виживаністю у 46\% та 5-річною виживаністю у 29\% [23]. Відзначають, що досягнення балансу між ризиком виникнення повторного ГІ та профі-
ПОКАЗАТЕЛИ ЛИПИДОГРАММЫ У БОЛЬНЫХ ГИПЕРТОНИЧЕСКОЙ БОЛЕЗНЬЮ, ОСЛОЖНЕННОЙ ГЕМОРРАГИЧЕСКИМ ИНСУЛЬТОМ, ПОСЛЕ РАННЕГО ВОССТАНОВИТЕЛЬНОГО ПЕРИОДА Ткачишин А.B.

Национальный медицинский университет им. А.А. Богомольца, г. Киев, Украина

Цель. Определить показатели липидограммы у больных гипертонической болезнью (ГБ), осложненной геморрагическим инсультом (ГИ), после раннего восстановительного периода; установить формулу расчета дозы розувастатина для таких больных и оценить профиль безопасности лечения им через 3 месяца от начала 1-месячного курса.

Материалы и методы. Было сформировано 2 группы пациентов: в основную группу вошло 107 человек (56 женщин и 51 мужчина, средний $(M \pm \sigma)$ возраст - $(54,0 \pm 9,5)$ года), перенесших ГИ как осложнение ГБ // стадии более 6 месяцев назад, в контрольную - 104 человека (54 женщины и 50 мужчин, средний возраст - (53,7士8,) года) с ГБ без перенесенного ГИ. Группы пациентов были сопоставимы по основным показате лям. Всем больным был проведен анализ крови с определением показателей липидограммы. Результаты. Параметры липидограммы в основной и контрольной группах $(M \pm \sigma)$ : общий холестерин - $(5,998 \pm 1,326)$ vs $(6,027 \pm 1,103)$ ммоль/л; триглицериды - $(1,422 \pm 0,775)$ vs $(1,975 \pm 1,136)$ ммоль/л; липопротеиды низкой плотности $(4,196 \pm 1,021)$ vs $(4,301 \pm 0,884)$ ммоль/л; липопротеиды очень низкой плотности $(0,619 \pm 0,356)$ vs $(0,719 \pm 0,268)$ ммоль/л; липопротеиды высокой плотности - $(1,418 \pm 0,301)$ vs $(1,318 \pm 0,252)$ ммоль/л, разница достоверна $(p<0,05) ;$ коэффициент атерогенности $(3,438 \pm 1,008)$ vs $(3,616 \pm 0,898)$.

Выводы. Больные, перенесшие ГИ как осложнение ГБ, выжили в течение первых 6 месяцев после ГИ, остались транспортабельными, восстановились до уровня 50-100 баллов по шкале Бартел по сравнению с больными ГБ, стадия II, имеют сопоставимые средние значения показателей липидограммы, кроме липопротеидов высокой плотности, которые выше у больных с перенесенным цереброваскулярным заболеванием. Разработана формула для подбора дозы розувастатина с получением результирующего уровня липопротеидов низкой плотности в диапазоне 2, 198-2,500 ммоль/л при лечении через 6 месяцев и более от случая ГИ. Определено, что при 1-месячном курсе лечения розувастатином лиц с перенесенным ГИ в течение ближайших 3-х месяцев после начала этого лечения не было выявлено неблагоприятных последствий в виде дальнейших осложнений ГБ.

Ключевые слова: геморрагический инсульт, гипертоническая болезнь, липидограмма, атеросклероз, статины.

() Ткачишин О.В. СТАТТЯ, 2019. 
INDICES OF LIPID PANEL IN PATIENTS WITH ESSENTIAL HYPERTENSION, COMPLICATED WITH HEMORRHAGIC STROKE, AFTER AN EARLY RECOVERY PERIOD

\section{Tkachyshyn O.V.}

Bogomolets National Medical University, Kyiv, Ukraine

Objective: to determine lipid panel indices in patients with essential hypertension (EH), complicated with hemorrhagic stroke (HS), after an early recovery period; to establish a formula for calculating the dose of rosuvastatin for such patients and to assess the safety profile of its treatment in 3 months after the starting date of 1-month treatment period. Materials and methods. There were formed 2 groups of people: 107 persons (56 women and 51 men, average $(M \pm \sigma)$ age - $(54,0 \pm 9,5)$ years) were involved in the main group, who have undergone $H S$ as a complication of EH 6 months and more previously; the comparison group comprised 104 persons ( 54 women and 50 men, middle age $(53,7 \pm 8,9)$ years old) with $E H$. They were matched groups according to key indicators. All the abovementioned people underwent blood analysis on lipid panel indices.

Results. Lipid panel indices in the main and control group $(M \pm \sigma)$ were the following ones, respectively: total cholesterol $(5,998 \pm 1,326)$ vs. $(6,027 \pm 1,103)$ $\mathrm{mmol} / \mathrm{l}$; triglycerides $(1,422 \pm 0,775)$ vs.

$(1,975 \pm 1,136) \mathrm{mmol} / \mathrm{l}$; low density lipoprotein $(4,196 \pm 1,021)$ vs. $(4,301 \pm 0,884) \mathrm{mmol} / \mathrm{l}$; very low density lipoprotein $(0,619 \pm 0,356)$ vs.

$(0,719 \pm 0,268) \mathrm{mmol} / \mathrm{l} ;$ high density lipoprotein $(1,418 \pm 0,301)$ vs. $(1,318 \pm 0,252) \mathrm{mmol} / \mathrm{l}$, the difference is significant $(p<0,05)$; the atherogenicity coefficient of $(3,438 \pm 1,008)$ vs. $(3,616 \pm 0,898)$.

Conclusions. Patients with $\mathrm{EH}$, who have suffered HS more than 6 months before and have recovered up to 50-100 points according to Barthel scale, compared with patients with EH stage II, have similar mean values of lipid panel indices, with the exception of high density lipoprotein index, which is bigger in patients with former cerebrovascular injury. A formula for selecting dosage of rosuvastatin has been developed to obtain the resulting low density lipoprotein level in the range 2, 198-2,500 $\mathrm{mmol} / \mathrm{l}$ for the treatment after 6 months period from the incidence case of HS. It was determined that in the next 3 months period in case of rosuvastatin treatment of persons with former HS during the one-month period, there are no adverse effects in the form of further complications of HS.

Keywords: hemorrhagic stroke, essential hypertension, lipid panel, atherosclerosis, statins. лактикою ішемічних судинних захворювань завдяки лікуванню статинами є складним завданням у цієї когорти осіб [20].

Наразі існує дуже мало проспективних рандомізованих досліджень, на основі яких можна було б оцінити вплив ініціації терапії статинами на основні клінічні наслідки після ГІ. Кілька ретроспективних мета-аналізів та досліджень баз даних показали зменшення величини показника смертності та покращання функціональних результатів при терапії статинами після ГІ. Проте у жодному 3 аналізів не було чітко визначено терміни ініціації лікування статинами після ГІ, тому вікно можливостей для початку терапії статинами широке, що вимагає обґрунтованої конкретизації часових рамок у подальших дослідженнях [23].

Варто відзначити, що у попередньому дослідженні нами було показано, що пацієнти, які перенесли ГІ за провідної участі у його розвитку гіпертонічної хвороби (ГХ), мають статистично значущо більший ризик розвитку атеросклерозу сонних артерій (ACA) та на пізніших стадіях порівняно 3 хворими на ГX II стадії [4]. Отже, отримані результати потре- бують доповнення вивченням показників ліпідограми та напрямків їх корекції.

Мета - визначити показники ліпідограми у хворих на ГХ, ускладнену ГІ, після раннього відновного періоду; встановити формулу розрахунку дози розувастатину для таких хворих та оцінити профіль безпеки лікування ним протягом 1місячного періоду за 3 місяці від початку лікування.

Матеріали і методи. Загалом у дослідження було залучено 211 осіб, з яких 110 жінок та 101 чоловік. Вони були поділені на 2 групи: основна та контрольна.

Формування основної групи складалося 3 двох етапів. На першому етапі проводили відбір хворих, які поступили на лікування з приводу перенесеного ГІ до клініки судинної нейрохірургії ДУ «Інститут нейрохірургії ім. А.П. Ромоданова НАМН України» у 2013-2017 роках. Враховуючи те, що причини ГІ мають великий спектр інших патологій, для формування однорідної групи нами було виключено хворих з іншими патологічними станами та захворюваннями, які потенційно можуть призвести до виникнення ГІ. Критерій включення: ГX ІІ стадії до ГІ. Відповідно саме факт перене- сення ГІ став причиною того, що при формулюванні діагнозу «ГХ» стадія ГХ змінена з II на III в осіб основної групи.

На другому етапі формування основної групи ретроспективно було виключено із подальшого дослідження померлих протягом перших 3-х періодів (найгостріший, гострий, ранній відновний - до 6 міс.) відповідно до класифікації Є.І. Гусєва та співавторів [1]. 3 анамнестичних даних пацієнтів відомо, що після перенесеного ГІ 7 (6,5\%) осіб з основної групи приймали гіполіпідемічні препарати (статини), 6 (5,6\%) - препарати $\omega$-3-поліненасичених жирних кислот близько місяця. На момент проведення обстеження жоден 3 хворих не перебував на лікуванні статинами.

Отже, основна група була сформована з тих пацієнтів, які вижили протягом перших трьох періодів ГІ, залишилися транспортабельними, відновилися неврологічно до рівня 50-100 балів за шкалою Бартел та не приймали гіполіпідемічних препаратів на момент обстеження. Контрольна група складалася 3 хворих на ГX, стадія II, які також не одержували гіполіпідемічної терапії. 
низької щільності (ЛПДНЩ), коефіцієнт атерогенності.

Статистична обробка отриманих даних здійснювалася за допомогою IBM SPSS Statistics Base v.22 на базі Національного медичного університету ім. О.О. Богомольця. Для порівняння ступеня однорідності (різноманітності) параметрів сукупностей розраховували коефіцієнт варіації:

$\mathrm{C}=$ (Середнє квадратичне від-

Основна група склала 107 осіб (62 з перенесеним ГІ внаслідок розриву мішкоподібної аневризми; 45 - внаслідок розриву артерії), контрольна група - 104 особи. Групи пацієнтів були співставними за основними показниками: вони не відрізнялися за віком $(54,0 \pm 9,5)$ років $(\mathrm{M} \pm \sigma)$ та $(53,7 \pm 8,9)$ років, основна та контрольна групи відповідно), статтю (56 жінок, 51 чоловік та 54 жінки, 50 чоловіків відповідно), індексом маси тіла $(28,79 \pm 4,33$ та 28,97 44,39 відповідно), наявністю цукрового діабету, розподілом населення на міське/сільське.

Крім того, у пацієнтів обох груп не спостерігалося порушень ритму серця на момент проведення обстеження. Пацієнтів 3 основної групи обстежували за 16,6士11,7 (6-51) місяців після ГІ.

Обстеження хворих тривало 3 листопада 2016 по липень 2018 року на базі кафедри пропедевтики внутрішньої медицини № 1 НМУ 3 аналізом венозної крови натще відповідно до визначеної методики. В осіб обох груп визначали такі показники ліпідограми: 3X, тригліцериди, ліпопротеїди високої щільності (ЛПВЩ), лПнЩ, ліпопротеїди дуже

хилення/Середнє арифметичне варіаційного ряду) · 100\%. кий рівень варіабельності. У таких рядах ми не викидали нетипові варіанти, а використовували непараметричні методи аналізу. Різниця між параметричними показниками оцінювалася за t-критерієм Ст'юдента, між непараметричними - за U-критерієм МаннаУїтні. Статистично значущі відмінності результатів досліджень визначали при рівні $p<0,05$.

Результати дослідження представлено у вигляді $\mathrm{M} \pm \sigma$.

Клінічне дослідження було проведено відповідно до Гельсинської декларації Всесвітньої медичної асоціації 12 «Етичні принципи медичних досліджень за участі людини в якості об'єкта дослідження» (1964, оновлена у 2000 р.). Кожен пацієнт або його законний представник заповнив Поінформовану згоду (Експертний висновок Комісії 3 питань етики Національного медичного університету імені О.О. Богомольця від 26.10.2016, протокол № 98).

Результати та їх обговорення. Було встановлено, що показники рівня тригліцеридів, лПДНЩ та коефіцієнта атеро-
При С >25\% визначали висо-

Таблиця 1

Показники ліпідограми досліджуваних груп

\begin{tabular}{|l|c|c|}
\hline & $\begin{array}{c}\text { Основна група, } \\
\mathrm{n}=105\end{array}$ & $\begin{array}{c}\text { Контрольна група, } \\
\mathrm{n}=104\end{array}$ \\
\hline 3Х, ммоль/л & $5,998 \pm 1,326$ & $6,027 \pm 1,103$ \\
\hline Тригліцериди, ммоль/л & $1,422 \pm 0,775$ & $1,975 \pm 1,136$ \\
\hline ЛПНЩ, ммоль/л & $4,196 \pm 1,021$ & $4,301 \pm 0,884$ \\
\hline ЛПДНщ, ммоль/л & $0,619 \pm 0,356$ & $0,719 \pm 0,268$ \\
\hline лПВЩ, ммоль/л & $1,418 \pm 0,301^{*}$ & $1,318 \pm 0,252$ \\
\hline Коефіцієнт атерогенності & $3,438 \pm 1,008$ & $3,616 \pm 0,898$ \\
\hline
\end{tabular}

Примітка: * - $p<0,05$, різниця статистично значуща за t-критерієм Ст'юдента. генності в обох групах належали до непараметричних, решта - до параметричних. Отримані середні значення показників ліпідограми представлено у таблиці 1.

Відповідно до отриманих даних показник ЛПВЩ в основній групі був статистично значущо більшим порівняно з контрольною, що може бути пояснено певними компенсаторними механізмами для збалансування більш вираженого атерогенного процесу у судинній стінці в основній групі, адже у попередньому нашому дослідженні було встановлено більшу частоту виявлення атеросклерозу магістральних артерій шиї та на пізніших стадіях - у хворих на ГХ, ускладненою ГІ [4]. Як відомо, ЛПВЩ мають багато антиатерогенних властивостей [18], що може свідчити про компенсаторний механізм їх підвищення в організмі у таких хворих.

Повідомляють, що більше числове значення частки при діленні 3X на холестерин ЛПВЩ призводить до зниження ризику ГІ, але й до підвищення ризику ішемічного інсульту [12]. Зважаючи на такі дані та отриману нами статистично значущу різницю між основною та контрольною групами за рівнем ЛПВЩ, ми порівняли досліджувані групи між собою за вищезазначеним співвідношенням. Отже, в основній групі воно становило $4,405 \pm 1,004$, у контрольній $4,620 \pm 0,626$. Різниця між групами не досягла статистично значущого рівня, хоча й наблизилася до нього (t-критерій Ст'юдента = 1,86), що свідчить про тенденцію до підвищеного ризику ГІ в основній групі порівняно з контрольною.

Зважаючи на отримані результати ліпідограми в обох групах, доцільним було надання рекомендацій щодо зміни способу життя (зокрема дієти) та проведення медикаментозної терапії за відсутності досягнення цільових показників 3X та ЛПНЩ. Ми розглядали саме статинотерапію як лікування, що довело свою ефективність у зниженні серцево-судинного ризику [23]. Крім холестеринознижуючого 
ефекту, статини, як відомо, мають плейотропні ефекти (протизапальну, антитромботичну, антиоксидантну та нейропротективну властивості) [23]. Саме антитромботичний ефект статинів і викликає широку дискусію з приводу доцільності використання цих препаратів у пацієнтів після ГІ через потенційний ризик повторних внутрішньочерепних кровотеч. Зазначається, що ініціювання статинотерапії після ГІ може бути доцільним у хворих у тих випадках, коли переваги перевищують потенційні ризики [23].

Незважаючи на нещодавнє виявлення покращання результатів лікування при використанні статинів під час госпіталізації повідомляють про підвищений ризик рецидиву ГІ у довгостроковій перспективі [15]. Проте визнають, що припинення лікування статинами у пацієнтів з сімейною гіперхолестеринемією погіршує наслідки ураження серцевосудинної системи і навіть підвищує загальну смертність 3 усіх причин. Відповідно, доцільним вважають безперервне лікування статинами у хворих на сімейну гіперхолестеринемію після гострого ГІ [25]. 3 приводу корекції рівня гіперхолестеринемії у вітчизняному протоколі лікування ГІ пацієнтам із групи високого та дуже високого ризику рекомендується підтримувати рівень $3 X<4,5$ ммоль/л та холестерину ЛПнЩ <2,5 ммоль/л. Щодо призначення статинів їх рекомендовано хворим, які мають високий та дуже високий ризик серцево-судинних захворювань і порушення обміну холестерину (3X>5,0 ммоль/л і холестерину ЛПНЩ
$>3,0$ ммоль/л), яке не піддається немедикаментозній корекції. Можливе призначення статинів за індивідуальним режимом [5].

Відзначається, що 3 метою профілактики інсульту терапія статинами має бути розпочата в усіх пацієнтів 3 доведеним атеросклеротичним ураженням судин [3]. Не рекомендується уникати терапії статинами через потенційний ризик ГІ [23]. Крім того, навіть було виявлено, що терапія статинами пов'язана з меншим ризиком ГІ порівняно з її відсутністю (Asberg та Eriksson, 2015) [7].

В одному міжнародному протоколі [8] зазначено, що більш інтенсивне зниження рівня ліпідів статинами пов'язане з меншим ризиком інсульту, а занепокоєння щодо підвищеного ризику ГІ під час лікування статинами не $€$ виправданим [8]. В американських рекомендаціях щодо статинотерапії відзначається, що ризик ГІ збільшується, але знижується загальний серцево-судинний ризик [15].

В іншому ж протоколі зазначено, що існує недостатньо даних, щоб рекомендувати обмеження використання статинів у хворих на перенесений ГІ [13]. А у нових Європейських рекомендаціях з ведення АГ (2018 рік) вказують, що хворі з атеросклеротичними бляшками сонних артерій мають високий ризик розвитку ішемічного інсульту внаслідок їх розриву, тому зниження АТ має бути доповнене, крім іншого, лікуванням статинами [26].

у великих мета-аналізах не було виявлено жодного зв'язку між лікуванням статинами або низьким рівнем холесте- рину ЛПНЩ з майбутнім ризиком ГІ, хоча ризик виникнення будь-якого інсульту, а також смертність були значно знижені [11].

Варто відзначити, що у деяких оглядових дослідженнях $є$ дані, що рівень $3 X$ у сироватці крови нижче 160 мг/дл $(4,138$ ммоль/л) та ЛПНЩ <85 мг/дл (2,198 ммоль/л) призводить до більшого ризику розвитку ГІ $[10,23]$.

Зважаючи на кілька переваг порівняно з іншими статинами, було обрано розувастатин для лікування хворих основної групи. Він є гідрофільним [17, 27], має менший ризик розвитку повторного ГІ протягом тривалого періоду спостереження (10 років) [20], має найбільшу відносну ефективність зниження ЛПНЩ $[6,23]$, ліпше покращує показник жорсткості артерій завдяки переважаючому зниженню рівня ЛПНЩ, має протизапальний ефект [14].

Зважаючи на все вищезазначене, ми розподілили хворих з основної групи на 4 підгрупи за рівнями ЗХ та ЛПНЩ, щоб виявити тих, для кого було б безпечним (згідно з вказаними вище літературними даними) призначення статинів, що сприятиме профі-

\section{Підбір дози розувастатину та прогнозування його гіполіпідемічної дії}

Таблиця 2

\begin{tabular}{|c|c|c|c|c|c|c|}
\hline Підгрупа & $\begin{array}{c}\text { Доза } \\
\text { розува- } \\
\text { статину } \\
\text { на добу }\end{array}$ & $\begin{array}{c}\text { Передбачуваний \% зниження } \\
\text { ЛПнщ при логарифмічному } \\
\text { вирівнюванні дозо-залежного } \\
\text { впливу (kn) }\end{array}$ & $3 \times$ & лпнщ & $\begin{array}{c}\text { Передбачу- } \\
\text { ваний ЛПнщ }\end{array}$ & $\begin{array}{c}\text { Кількість } \\
\text { хворих }\end{array}$ \\
\hline 1 & - & $-(\mathrm{k} 0)$ & $4,872 \pm 0,597$ & $3,234 \pm 0,329$ & - & 42 \\
\hline 2 & 5 мг & $41,4(\mathrm{k} 1)$ & $5,693 \pm 0,131$ & $3,930 \pm 0,014$ & $2,303 \pm 0,008$ & 14 \\
\hline 3 & 10 мг & $45,8(\mathrm{k} 2)$ & $5,960 \pm 0,212$ & $4,110 \pm 0,042$ & $2,228 \pm 0,023$ & 7 \\
\hline 4 & 20 мг & $50,2(\mathrm{k} 3)$ & $6,567 \pm 0,410$ & $4,640 \pm 0,170$ & $2,311 \pm 0,085$ & 23 \\
\hline 5 & $20 \mathrm{мг}$ & $50,2(\mathrm{k} 3)$ & $7,898 \pm 1,176$ & $5,633 \pm 0,622$ & $2,805 \pm 0,310$ & 21 \\
\hline
\end{tabular}


нюючи попередні дані, для визначення оптимальної дози ми використали систему рівнянь при плануванні результуючих показників:

$$
\left\{\begin{array}{l}
\mathrm{y}=\mathrm{x} \cdot\left(100-\mathrm{k}_{\text {найбільше }}\right) / 100 \\
2,198>\mathrm{y}<2,500
\end{array}\right.
$$

де $x$ - наявний рівень ЛПНЩ, у - передбачуваний рівень при

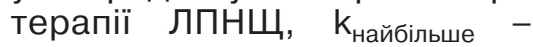
передбачуваний \% зниження ЛПНЩ при логарифмічному вирівнюванні дозо-залежного впливу (kn) (табл. 2).

lз 65 осіб, яким було призначено розувастатин у відповідному дозуванні протягом одного місяця, під час телефонного інтерв'ю за місяць 29 $(44,6 \%)$ повідомили, що почали лікування, решта (з різних причин) не починали лікування. 3 тих, що почали лікування, у 14\% (4 особи) виявилася побічна дія у вигляді міопатії, тому вони припинили приймати розувастатин. Ті, що пройшли увесь курс 1-місячного лікування (25 осіб), були оцінені у форматі «випадок серцево-судинного ускладнення - 0» після завершення курсу прийому препарату, а також через 3 місяці. У жодного із них не було повторного ГІ чи смерті на відміну від тих, хто не починав лікування: 2 летальних випадки протягом трьох місяців. 3 етичних та технічних міркувань причини смертельних випадків встановити не вдалося, а зазначена їх кількість протягом вказаного періоду часу не дозволяє встановити статистично значущу різницю між групами.

\section{Висновки}

1. Хворі, які перенесли ГІ, асоційований з АГ, вижили протягом перших 6 місяців після ГІ, залишилися транспортабельними, відновилися до рівня 50-100 балів за шкалою Бартел порівняно з хворими на ГХ, стадія II, мають співставні середні значення показників ліпідограми, окрім ЛПВЩ, який більший у хворих 3 перенесеним цереброваскулярним захворюванням.

2. Розроблено формулу підбору дози розувастатину 3 результуючим рівнем ЛПНЩ у діапазоні 2,198-2,500 ммоль/л для лікування після 6 місяців від випадку ГІ. Визначено, що у найближчий 3-місячний період при лікуванні розувастатином протягом 1-го місяця осіб з перенесеним ГІ не було виявлено несприятливих наслідків у вигляді подальших ускладнень ГХ.

Конфлікт інтересів. Дослідження проводилося відповідно до Договору № 07 про наукове співробітництво між ДУ «Інститут нейрохірургії імені академіка А.П. Ромоданова НАМН України» та Національним медичним університетом імені О.О. Богомольця від 21.01.2016 p.

Жодна із сторін дослідження не мала фінансових інтересів.

\section{ЛІТЕРАТУРА}

1. Гусев Е.И., Скворцова В.И., Чекнева Н.С. и др. Лечение острого мозгового инсульта (диагностические и терапевтические алгоритмы) : учебно-методическая литература. М., 1997.

2. Литовский И.А. Гордиенко А.В. Атеросклероз и гипертоническая болезнь: вопросы патогенеза, диагностики и лечения. СПб. : СпецЛит, 2013. 304 с.

3. Профілактика серцевосудинних захворювань. Адаптована клінічна настанова, заснована на доказах / Державний експертний центр МОЗ України; Асоціація кардіологів України. 2016. 127 с. URL : http://www. volyncard. in.ua/files/protocols/2016 564 AKN PSSZ.pdf

4. Ткачишин О.В.

Ультразвукова оцінка гемодинаміки та морфології магістральних артерій шиї у хворих на гіпертонічну хворобу, асоційовану з геморагічним інсультом. Український нейрохірургічний журнал. 2018. № 2. C. 69-78. DOI 10.25305/unj. 129636

5. Уніфікований клінічний протокол екстреної, первинної, вторинної (спеціалізованої), третинної (високоспеціалізованої) медичної допомоги та медичної реабілітації «Геморагічний інсульт (внутрішньомозкова гематома, аневризмальний субарахноїдальний крововилив)» : Наказ МОЗ України від 
17.04.2014 № 275. URL : http://mtd.dec.gov.ua/ images/dodatki/2014_275_Gl/2 014275 YKPMD Gl.p df

6. Adams S.P., Sekhon S.S., Wright J.M. Lipid-lowering efficacy of rosuvastatin. Cochrane Database Syst Rev. 2014.

№ 11. CD010254. doi: 10.1002/14651858.CD010254. pub2

7. Asberg S., Eriksson M. Statin therapy and the risk of intracerebral haemorrhage: a nationwide observational study. Int. J. Stroke. 2015. № 10. P. 46-49.

8. Catapano A.L., Graham I., De Backer G., Wiklund O., Chapman M.J., Drexel H. et al. 2016 ESC/EAS Guidelines for the Management of Dyslipidaemias: The Task Force for the Management of Dyslipidaemias of the European Society of Cardiology (ESC) and European Atherosclerosis Society (EAS) Developed with the special contribution of the European Assocciation for Cardiovascular Prevention \& Rehabilitation (EACPR). Atherosclerosis. 2016. Vol. 253. P. 281-344. doi: 10.1016/j.atherosclerosis. 2016.08.018.

9. Chen J.H., Wu T., Yang L.K., Chen L., Zhu J., Li P.P., Hu X., Wang Y.H. Protective effects of atorvastatin on cerebral vessel autoregulation in an experimental rabbit model of subarachnoid hemorrhage. Mol Med Rep. 2018. Vol. 17 (1). P. 1651-1659. doi: 10.3892/mmr.2017.8074.

10. Chen Yu-Wei, Li ChenHua, Yang Chih-Dong, Liu Chung-Hsiang, Chen ChihHung, Sheu Jau-Jiuan et al. Taiwan Stroke Registry Investigators. Low cholesterol level associated with severity and outcome of spontaneous intracerebral hemorrhage: Results from Taiwan Stroke Registry. PLoS One. 2017. Vol. 12 (4). e0171379. doi: 10.1371/journal.pone.0171379.

11. Endres M., Nolte C.H., Scheitz J.F. Statin Treatment in Patients With Intracerebral Hemorrhage. Stroke. 2018. Vol. 49 (1). P. 240-246. doi: 10.1161/STROKEAHA.117.019322.
12. Ferket B.S., van Kempen B.J., Wieberdink R.G., Steyerberg E.W., Koudstaal P.J., Hofman A., Shahar E. et al. Separate prediction of intracerebral hemorrhage and ischemic stroke. Neurology. 2014. Vol. 82 (20). P. 1804-1812. doi: 10.1212/WNL.0000000000000 427.

13. Hemphill JC 3-rd, Greenberg S.M.,

Anderson C.S., Becker K.,

Bendok B.R., Cushman M. et al. Guidelines for the

Management of Spontaneous Intracerebral Hemorrhage:

A Guideline for Healthcare

Professionals

From the American Heart

Association/American Stroke

Association. Stroke.

2015. Vol. 46 (7)

P. 2032-2060. doi: 10.1161/

STR.0000000000000069.

14. Hongo M., Kumazaki S., Izawa A., Hidaka H., Tomita T., Yazaki Y., Kinoshita O., Ikeda U. Low-dose rosuvastatin improves arterial stiffness in high-risk Japanese patients with dyslipdemia in a primary prevention group. Circ J. 2011. Vol. 75 (11). P. 2660-2667. 15. Jellinger P.S.,

Handelsman Y., Rosenblit P.D. Bloomgarden Z.T., Fonseca V.A., Garber A.J. et al. American association of clinical endocrinologists and American college of endocrinology guidelines for management of dyslipidemia and prevention of cardiovascular disease.

Endocr Pract. 2017. Vol. 23

(Suppl 2). P. 1-87. doi: 10.4158/EP171764.APPGL.

16. Kirkpatrick P.J.,

Turner C.L., Smith C.,

Hutchinson P.J., Murray G.D.

STASH Collaborators

Simvastatin in aneurismal subarachnoid haemorrhage

(STASH): a multicentre randomized phase 3 trial. Lancet

Neurol. 2014. Vol. 13 (7).

P. 666-675. doi:

$10.1016 /$ S1474-

4422(14)70084-5.

17. Kotl ga D., Masztalewicz M., Cie wie S., Nowacki P. Potential role of statins in the intracerebral hemorrhage and subarachnoid hemorrhage. Neurol Neurochir Pol. 2015. Vol. 49 (5)
P. 322-328. doi:

10.1016/j.pjnns.2015.07.007.

18. Ouweneel A.B.

Van Eck M. Lipoproteins as modulators of atherothrombosis: From endothelial function to primary and secondary coagulation. Vascul Pharmacol. 2016. Vol. 82. P.1-10. doi:

10.1016/j.vph.2015.10.009.

19. Pandit A.K., Kumar P., Kumar A., Chakravarty K., Misra S., Prasad K. High-dose statin therapy and risk of intracerebral hemorrhage: a metaanalysis. Acta Neurol Scand. 2016. Vol. 134 (1). P. 22-28. doi: 10.1111/ane.12540.

20. Tai S.Y., Lin F.C., Lee C.Y., Chang C.J., Wu M.T., Chien C.Y. Statin use after intracerebral hemorrhage: a 10-year nationwide cohort study. Brain Behav. 2016. Vol. 6 (8). e00487. doi: 10.1002/brb3.487.

21. Tapia-Perez H., SanchezAguilar M., Torres-Corzo J.G., Rodriguez-Leyva I., GonzalezAguirre D., Gordillo-Moscoso A., Chalita-Williams C. Use of statins for the treatment of spontaneous intracerebral hemorrhage: results of a pilot study. Cent Eur Neurosurg. 2009.

Vol. 70 (1). P. 15-20. doi: 10.1055/s-0028-1082064.

22. Uekawa K., Hasegawa Y., Ma M., Nakagawa T., Katayama T., Sueta D.,

Toyama K., Kataoka K. et al. Rosuvastatin ameliorates early brain injury after subarachnoid hemorrhage via suppression of superoxide formation and nuclear factor-kappa B activation in rats. J Stroke

Cerebrovasc Dis. 2014. Vol. 23

(6). P. 1429-1439. doi:

10.1016/j.jstrokecerebrovasdis.2013.12.004

23. Van Matre E.T., Sherman D.S., Kiser T.H.

Management of intracerebral hemorrhage - use of statins. Vasc Health Risk Manag. 2016 Vol. 12. P. 153-161. doi: 10.2147/VHRM.S75399.

24. Versmissen J., Scheele M., Dippel D.W., van den Meiracker A.H. [Statins after intracerebral haemorrhage: is this safe?]. Ned Tijdschr Geneeskd. 2015. Vol. 159. A8563.

25. Vuorio A., Kaste M., Kovanen P.T. Combination of intracerebral haemorrhage and 
familial hypercholesterolemia in the acute hospital setting - a challenge for statin treatment? Int J Stroke. 2015. Vol. 10 (4). P. 467-8. doi: 10.1111/ijs. 12492. PubMed PMID: 25973703.

26. Williams B., Mancia G., Spiering W., Agabiti Rosei E., Azizi M., Burnier M., Clement D.L., Coca A. et al. 2018 ESC/ESH Guidelines for the management of arterial hypertension. European Heart Journal. 2018. Vol. 39. P. 3021 3104.

DOI:10.1093/eurheartj/ehy339

27. Wood W.G., Eckert G.P., Igbavboa U., Muller W.E. Statins and neuroprotection: a prescription to move the field forward. Ann N Y Acad Sci. 2010. 1199. P. 69-76.

REFERENCES

1. Gusev E.I., Skvortsova V.I., Cheknev N.S. et al. Lechenie ostrogo mozgovogo insulta (diagnosticheskie i terapevticheskie algoritmy) : uchebnometodicheskaya literatura [Treatment of Acute Cerebral Stroke (Diagnostic and Therapeutic Algorithms) : Teachingand-Methodical Literature]. Moscow; 1997 (in Russian).

2. Litovskiy I.A. and Gordienko A.V. Ateroskleroz i gipertonicheskaya bolezn: voprosy patogeneza, diagnostiki i lechenija [Atherosclerosis and Hypertension: Issues of Pathogenesis, Diagnosis and Treatment]. Sankt-Peterburg : SpetsLit ; 2013 : 304 p. (in Russian).

3. Profilaktyka sertsevosudynnykh zakhvoriuvan. Adaptovana klinichna nastanova, zasnovana na dokazakh [Prevention of Cardiovascular Diseases. Adapted Clinical Instruction Based on the Evidences / State Expert Center of the Ministry of Health of Ukraine ; Association of the Cardiologists of Ukraine]. 2016 : 127 p. URL : http://www. volyncard.in.ua/files/protocols/2016 564_AKN_PSSZ.pdf (in Ukrainian).

4. Tkachyshyn O.V. Ukrainian Neurosurgical Journal. 2018 ; 2 : 69-78. DOI 10.25305/unj. 129636 (in Ukrainian)

5. Unifikovanyi klinichnyi protocol ekstrenoi, pervynnoi, vtorynnoi (spetsializovanoi) medychnoi dopomohy ta medychnoi reabilitatsii «Hemorahichnyi insult (vnutrishnomozkova hematoma, anevryzmalnyi subarakhnoidalnyi krovovylyv)»: nakaz MOZ Ukrainy vid 17.04.2014 № 275 [Unified Clinical Protocol of Urgant, Primary, Secondary (Specialized), Tertiary (Highly Specialized) Medical Aid and Medical Rehabilitation «Hemorrhagic Stroke (Intracerebral Hematoma, Aneurysmal Subarachnoid Hemorrhage)»: Order of the Ministry of Health of Ukraine, 17 April, 2014, No. 275.]. URL : http://mtd.dec.gov.ua/images/ dodatki/2014 275 Gl/2014 27 5_YKPMD_GI.pdf (in Ukrainian).

6. Adams S.P., Sekhon S.S. and Wright J.M. Cochrane Database Syst Rev. 2014 ; 11 : CD010254. doi: $10.1002 / 14651858$.

CD010254.pub2

7. Asberg S. and Eriksson M. Int. J. Stroke. $2015 ; 10: 46-49$.

8. Catapano A.L., Graham I., DeBacker G., Wiklund O. Chapman M.J., Drexel H. et al. Atherosclerosis. 2016; 253 :

281-344. doi: 10.1016/j.atherosclerosis.2016.08.018

9. Chen J.H., Wu T., Yang L.K., Chen L., Zhu J., Li P.P., Hu X. and Wang Y.H. Mol Med Rep. 2018 ; 17 (1) : 1651-1659. doi: 10.3892/mmr.2017.8074.

10. Chen Yu-Wei, Li ChenHua, Yang Chih-Dong, Liu Chung-Hsiang, Chen ChihHung, Sheu Jau-Jiuan et al. PLoSOne. 2017 ; 12 (4) : e0171379. doi: 10.1371/

journal.pone.0171379.

11. Endres M., Nolte C.H. and Scheitz J.F. Stroke. 2018 ; 49 (1) :240-246. doi: 10.1161/STROKEAHA. 117.019322.

12. Ferket B.S., van Kempen B.J., Wieberdink R.G., Steyerberg E.W., Koudstaal P.J., Hofman A., Shahar E. et al. Neurology. 2014 ; 82 (20) : 1804-1812. doi: 10.1212/WNL.

0000000000000427

13. Hemphill JC 3-rd, Greenberg S.M., Anderson C.S.,

Becker K., Bendok B.R.,

Cushman M. et al. Stroke. 2015 ; 46 (7) : 2032-2060. doi: 10.

$1161 /$ STR.0000000000000069.

14. Hongo M., Kumazaki S., Izawa A., Hidaka H., Tomita T., Yazaki Y., Kinoshita O. and Ikeda U. Circ J. 2011 ; 75 (11) : 2660-2667.

15. Jellinger P.S., Handelsman Y., Rosenblit P.D., Bloomgarden Z.T., Fonseca V.A.,
Garber A.J. et al. Endocr Pract. 2017 ; 23(Suppl 2) : 1-87. doi: 10.4158/EP171764.APPGL.

16. Kirkpatrick P.J., Turner C.L., Smith C., Hutchinson P.J. and Murray G.D. Lancet Neurol. 2014 ; 13 (7) : 666-675. doi: 10.1016/ S1474-4422(14)70084-5.

17. Kotl ga D., Masztalewicz M. Cie wie S. and Nowacki P. Neurol Neurochir Pol. 2015 ; 49 (5) : 322-328. doi:

10.1016/j.pjnns.2015.07.007.

18. Ouweneel A.B. and Van Eck M. Vascul Pharmacol. 2016; 82: 1-10. doi: 10.1016/j.vph. 2015.10.009.

19. Pandit A.K., Kumar P., Kumar A., Chakravarty K., Misra S. and Prasad K. Acta Neurol Scand. 2016 ; 134 (1) : 22-28. doi: 10.1111/ane.12540.

20. Tai S.Y., Lin F.C., Lee C.Y., Chang C.J., Wu M.T. and Chien C.Y. Brain Behav. 2016 ; 6 (8) : e00487. doi: 10.1002/brb3.487.

21. Tapia-Perez H., SanchezAguilar M., Torres-Corzo J.G., Rodriguez-Leyva I., GonzalezAguirre D., Gordillo-Moscoso A. and Chalita-Williams C. Cent Eur Neurosurg. 2009 ; 70 (1) : 15-20. doi: $10.1055 / \mathrm{s}-0028-$ 1082064.

22. Uekawa K., Hasegawa Y., Ma M., Nakagawa T., Katayama T., Sueta D., Toyama K., Kataoka K. et al. J Stroke Cerebrovasc Dis. 2014 ; 23 (6) : 1429-1439. doi:

10.1016/j.jstrokecerebrovasdis.2013.12.004.

23. Van Matre E.T., Sherman D.S. and Kiser T.H. Vasc Health Risk Manag. 2016 ; 12 : 153-161. doi: 10.2147/VHRM.S75399.

24. Versmissen J., Scheele M., Dippel D.W. and van den Meiracker A.H. Ned Tijdschr Geneeskd. 2015 ; 159. A8563 (in Dutch).

25. Vuorio A., Kaste M. and Kovanen P.T. Int J Stroke. 2015 ; 10 (4) : 467-8. doi:

10.1111/ijs.12492. PubMed PMID: 25973703.

26. Williams B., Mancia G., Spiering W., Agabiti Rosei E., Azizi M., Burnier M., Clement D.L., Coca A. et al. European Heart Journal. 2018 ; 39 : 3021-3104. DOI:10.1093/eurheartj/ehy339

27. Wood W.G., Eckert G.P., Igbavboa U. and Muller W.E. Ann N Y Acad Sci. 2010 ; $1199: 69-76$.

Надійшла до редакції 18.12.2018 


\section{PROBLEMS OF MONITORING OF THE HEALTH PRESERVING COMPETENCE IN MODERN ADOLESCENIS}

Tekliuk R.V., Serheta I.V.

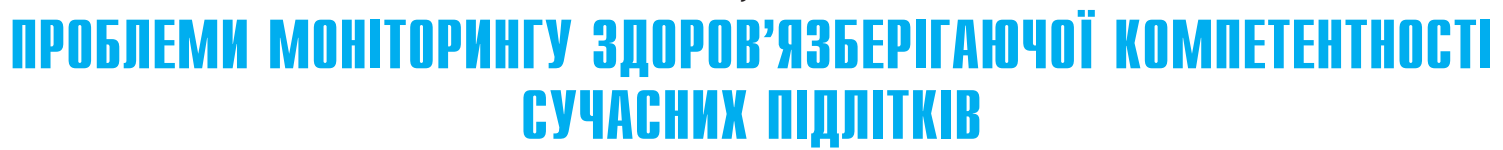

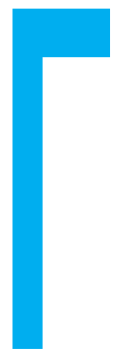

ТЕКЛЮК Р.В., CEPTETA I.B.

Вінницький національний медичний університет ім. М.І. Пирогова, м. Вінниця, Україна

teklyukru@gmail.com, serheta@ukr.net

ігієна дітей і підлітків має бути лідером змін у системі охорони здоров'я не тільки тому, що підлітки найближчим часом стануть працездатними дорослими $з$ найдовшим функціональним ресурсом, але й тому, що вони $€$ найактивнішими агентами змін, які відбуваються у багатьох суспільних сферах, у тому числі й у сфері громадського здоров'я. На відміну від людей середнього і літнього віку підлітки, як і молодь, швидко й енергійно реагують на усі суспільні зрушення, що, незаперечно, відображається на їхній здоров'язберігаючій діяльності. У світі відбуваються глобальні зміни, змінюється також і молоде покоління. Необхідно відзначити, що підлітки виявляються найпершими і наймасовішими жертвами не відомих донині ризиків: онлайн-геймерства та участі в Інтернет-спільнотах, які провокують спроби суїциду; багатогодинного нічного спілкування у чатах; зйомок «селфі» в екстремально-небезпечних місцях тощо. Що вже казати про спроможність підлітків опиратись пропозиціям спробувати наркотик, якщо засоби масової інформації блискавично поширюють відомості про те, що знаменитий бізнесмен Ілон Маск (багато для кого він є втіленням передової людини) вживає марихуану у прямому ефірі своєї передачі. В Україні додатковим негативним фактором впливу на здоров'я дітей і
ПРОБЛЕМЫ МОНИТОРИНГА ЗДОРОВЬЕСБЕРЕГАЮЩЕЙ КОМПЕТЕНТНОСТИ СОВРЕМЕННЫХ ПОДРОСТКОВ

Теклюк Р.В., Сергета И.В.

Винницкий национальный медицинский университет им. Н.И. Пирогова, г. Винница, Украина

Целью работы было определение проблемных сторон проведения мониторинга здоровьесберегающей компетентности современных подростков в свете изменений способа жизни современных школьников, оказывающих влияние на их здоровье.

Материалом исследования стали данные анкетирования, проведенного среди подростков 14-17 лет, обучающихся в общеобразовательных школах г. Винницы в 2003, 2009, 2013, 2017 годах. Статистическая обработка данных проводилась с использованием программы «Statistica 6.1», включая такие методы, как дескриптивная статистика, определение критерия Стьюдента для независимых выборок, Q критерия Кохрена и коэффициента корреляции Спирмена.

Результаты пятнадцатилетнего исследования свидетельствуют о том, что стиль жизни подростков изменяется, однако не существует однозначного ответа на вопрос, становится ли он более либо, наоборот, менее благоприятным для здоровья. В частности, за это время улучшились знания подростков в области контрацепции, однако не произошло позитивного сдвига в их понимании рисков раннего начала половой жизни. В среднем у половины подростков отмечаются недостаточные знания таких практических вопросов в области здоровьесбережения, как методы профилактики ОРВИ, доврачебные действия при ожогах, пищевых отравлениях, расчета калорийности питания и т.д.

Распространение разнообразных «гаджетов» повлияло на формы времяпровождения: просмотр телепередач уступил место «общению» с компьютером; подростки чаще находятся вне дома, что, однако, не означает, что они ведут активный образ жизни. Телефон и Интернет стали причинами существенной недостаточности сна. В то же время зафиксировано увеличение физической активности, снижение первых и последующих попыток курения среди юношей, уменьшение количества девушек со сформированной привычкой табакокурения. Происходит сдвиг первых попыток употребления алкоголя на более поздний подростковый возраст, уменьшение количества юношей, которые когда-либо пребывали в состоянии выраженного опьянения. Выводы. Сравнение отдельных показателей медицинской грамотности, определение мотивации к ведению здорового способа жизни и поведенческих рисков среди подростков показали, что мониторинг здоровьесберегающей компетентности школьников следует проводить в трех вышеназванных направлениях с учетом существующих тенденций и гендерных особенностей формирования здоровьесберегающего поведения подростков, а также последствий воздействия социальных изменений и научнотехнического прогресса. При разработке инструмента для проведения данного мониторинга следует учитывать следующие характеристики: комплексность, лаконичность и чувствительность, учет пола и возраста, открытость к новым модификациям.

() Теклюк Р.В., Сергета І.В. СТАТтЯ, 2019. 